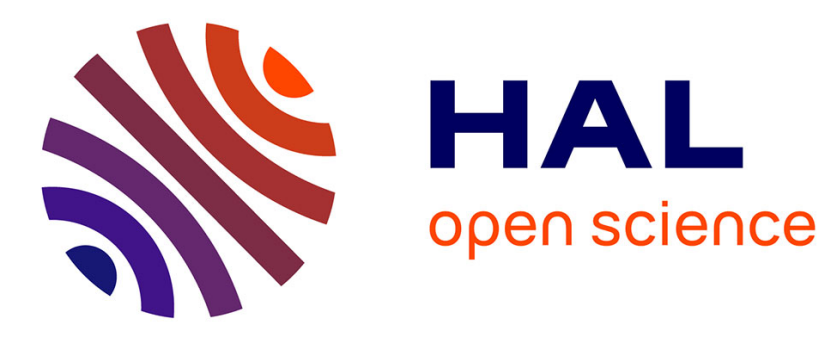

\title{
The linguistic archeology of the Ryukyu Islands
}

Thomas Pellard

\section{To cite this version:}

Thomas Pellard. The linguistic archeology of the Ryukyu Islands. Heinrich, Patrick; Miyara, Shinsho; Shimoji, Michinori. Handbook of the Ryukyuan languages: History, structure, and use, De Gruyter Mouton, pp.13-37, 2015, 978-1-61451-161-8. 10.1515/9781614511151.13 . hal-01289257

\section{HAL Id: hal-01289257 https://hal.science/hal-01289257}

Submitted on 26 May 2016

HAL is a multi-disciplinary open access archive for the deposit and dissemination of scientific research documents, whether they are published or not. The documents may come from teaching and research institutions in France or abroad, or from public or private research centers.
L'archive ouverte pluridisciplinaire HAL, est destinée au dépôt et à la diffusion de documents scientifiques de niveau recherche, publiés ou non, émanant des établissements d'enseignement et de recherche français ou étrangers, des laboratoires publics ou privés. 


\section{The linguistic archeology of the Ryukyu Islands}

Published in Patrick Heinrich, Shinsho Miyara \& Michinori Shimoji (eds.). 2015. Handbook of the Ryukyuan languages: History, structure, and use. Berlin; Boston: De Gruyter Mouton, p. 13-37. ISBN: 978-1-61451-161-8, DOI: 10.1515/9781614511151.13.

Thomas PELLARD (CNRS-CRLAO)

\section{What, if anything, is Ryukyuan?}

What are the Ryukyuan languages? ${ }^{1}$ How and whence did these languages arise and diversify? The history of the evolution of the Ryukyuan languages is a fundamental issue that still remains by and large unsolved.

The study of the prehistory of human populations is not the preserve of archaeology, but is located at the interface with other disciplines such as anthropology and linguistics. In particular, the insights from historical linguistics have proven especially valuable (Diamond \& Bellwood 2003), and though it is often not possible to establish a straightforward equation between a people, a culture, and a language, the history of languages is obviously inseparable from that of their speakers. Since each discipline has its own limitations, the only viable approach to a holistic reconstruction of the past of human populations is an interdisciplinary one, a "new synthesis" (Renfrew 1992) that triangulates the different kinds of evidence offered by archaeology, anthropology, and linguistics.

Traditionally, the term "Ryukyuan" designates the native languages of the chain of islands ranging from Amami Ōshima and Kikai in the north to Hateruma and Yonaguni in the southwest. But are these really a valid subgroup of closely related languages or just a collection of lookalikes that happen to be spoken in the same area? Are they sister languages of Japanese, do they belong to a Western branch of Japanese, or something else? What, if anything, is Ryukyuan? Unfortunately, this fundamental question has not been fully investigated as yet.

Appearances can be deceptive, and both biology and linguistics sometimes revise classifications based on similarities. Whales are not fishes, and birds, although they are usually not considered to be reptiles, are more closely related to crocodiles than lizards are. Similarly, Vietnamese is not related to Chinese or Thai, though all three of them are mainly monosyllabic and have similar tone systems. Species, both living and linguistic, can undergo similar evolutions independently, and languages are also known to be prone to converge along the same evolutionary paths as their neighbors.

1. I take here the practical view that there are five distinct Ryukyuan languages: Amami, Okinawan, Miyako, Yaeyama, and Dunan (Yonaguni). However, several other languages should probably be recognized, especially within the Yaeyama group, as some varieties are reported to be not mutually intelligible (Reiko Aso p.c. 2011, personal field notes). 


\subsection{Trees and branches: Why and how do we classify languages?}

The classification of languages and living organisms in terms of shared ancestry is an important part of respectively linguistics and biology, and the two have a long history of mutual influence (Atkinson \& Gray 2005). Classifications most often take the shape of the well known tree diagram, but tree diagrams are not a goal in themselves. They only represent in a convenient way information about history, and what is important is just that information. Classifications, by summarizing their evolutionary history, or phylogeny, help us understand why languages or organisms are the way they are.

Phylogenetic classifications group together species that share the same innovations inherited from a recent common ancestor. They are better suited for reconstructing evolutionary history than traditional phenetic classifications based on the quantification of surface similarities, since those can be archaisms or pure coincidences. One linguistic analogue of the phenetic approaches in biology is lexicostatistics, a method which measures the number of words shared between languages in order to infer subgroups. But lexicostatistics does not distinguish between innovations and retentions, and it thus tends to group together conservative languages rather than languages with shared innovations. Lexicostatistical estimates of the relative proximity between the Ryukyuan languages and their relative distance to Japanese (Hattori 1959: 228, Ōshiro 1972) should thus not be taken at face value.

Among the various types of linguistic innovations that can be used to establish subgroups, some are more reliable than others. We should thus draw evidence from linguistic domains less prone to parallel development and borrowing, in order to minimize the effects of chance and contact. Sound changes are an often used criterion, but this should be done only cautiously for two reasons. ${ }^{2}$ First, some sound changes are due to natural tendencies and occur independently in many unrelated languages, like the palatalization of consonants near front vowels or the spirantization of $k$ into $h$ or of $p$ into $f$ or $\phi$. Second, sound changes tend to diffuse geographically, even across language boundaries. ${ }^{3}$ This is why classifications based on sound changes are often inconclusive and conflict with other criteria. Innovations in the basic lexicon and the morphology constitute far more reliable evidence for subgrouping, especially when they involve irregular changes.

Listing and fully justifying every innovation supporting the different branches of the Japonic tree in Figure 1.1 is beyond the scope of this chapter, and the following sections will thus give only a limited number of the most convincing ones.

2. See Sagart (2004) for a criticism of classifications of Austronesian based on sound changes. 3. As in the well known example of the spread of uvular $r$ across Europe under the influence of Parisian French (Trudgill 1974). 


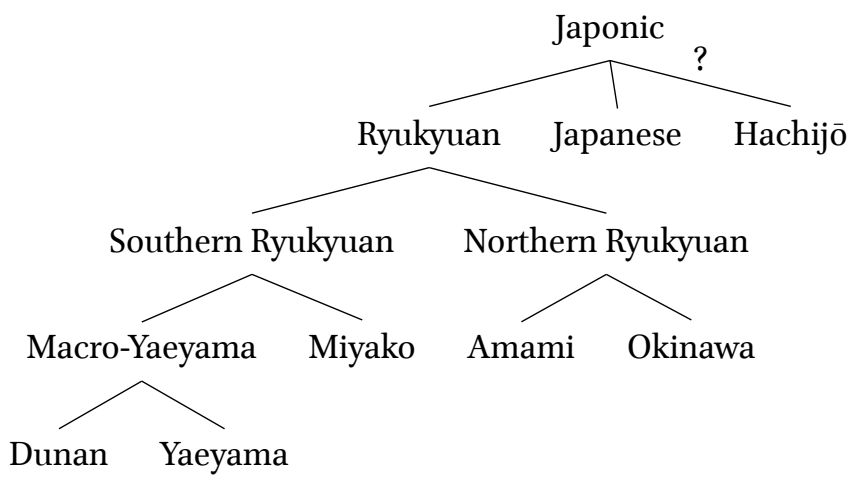

Figure 1.1: The Japonic language family tree

\subsection{The Ryukyuan languages and their relationship with Japanese}

Though it is generally assumed that the Japonic family has two main branches (Katō 1977), a Japanese one and a Ryukyuan one, some scholars have challenged the very idea that the Ryukyuan languages form a valid subgroup (Unger 20o9: 94-106).

Still, a systematic comparison of the Ryukyuan and Japanese languages reveals all Ryukyuan varieties share a set of innovations absent from Japanese ( $\mathrm{Pel}-$ lard 2009: 249-275). For instance, all Ryukyuan languages share a Proto-Ryukyuan (PR) etymon *do C 'body' (Shodon dǔu, Shuri dú:, Ōgami tur, Ishigaki dú:, Dunan $d \hat{u}$ :). Proto-Ryukyuan further innovated by grammaticalizing this noun into a reflexive pronoun. Other Ryukyuan innovations include for example the semantic change 'intestines' > 'belly' for PR *wata B < Proto-Japonic (PJ) *wata 2.3b (Shodon wáthă, Shuri wátá, Ōgami pata, Ishigaki bádá, Dunan bàtà). The interrogative pronoun ${ }^{*} \mathrm{n}[\mathrm{a} \mid \mathrm{o}][\mathrm{o} \mid \mathrm{u}] \mathrm{C}$ 'what' (Shodon nǔz, Shuri nú:, Ōgami nau, Ishigaki nór, Dunan nû:) and the plural markers *-kjaa and *-taa (Shodon $-k^{h j a}$, Shuri -t6a:, -tar, Ōgami - ke:, -tar, Ishigaki -kja:, -ta:, Dunan -nta) are also unique to Ryukyuan, but these could also be retentions.

On the other hand, all Japanese dialects seem to share the forms otoko for 'man' (< 'young man'; Iwate òdògó, Tokyo òtókó('), Kyoto ótòkò, Izumo òtókó( '), Nagasaki òtòkó, Ōita òtókó(')) and kami for 'hair (of the head)' (< 'top, chief'; Iwate kàmít('), Tokyo kàmí('), Kyoto kámì, Izumo kàmé('), Nagasaki kàmí, Ōita kàmí(')) (Pellard 2009: 249-275).

The position of the Hachijō language is unclear ${ }^{4}$ and deserves more investigation, but since it does not share any of the above innovations, it may constitute a third primary branch. However, no evidence is found to support Hattori's (1976) idea that Hachijō might have been the first variety to branch off ProtoJaponic, and that Japanese and Ryukyuan thus might form a subgroup. Similarly, the hypothesis by Thorpe (1983: $236-238)$ that Ryukyuan is most closely related

4. Hachijō preserves many archaic lexical and grammatical features, but it also shows an important number of borrowings from Mainland Japanese. Any study on the phylogenetic position of Hachijō will need to first disentangle its different strata. 
to Eastern Old Japanese (the probable ancestor of Hachijō) is not supported linguistically, and his idea Eastern Japan was settled from Kyushu by leapfrogging over Central Japan is not backed up by any evidence.

Since Ryukyuan is a sister and not a daughter language of Japanese, it follows that the Ryukyuan data is at least as important as the Old Japanese texts, and that any feature reconstructible at the Proto-Ryukyuan level potentially goes back to Proto-Japonic, even if there is no trace whatsoever of it in Japanese. ${ }^{5}$

\subsubsection{Northern Ryukyuan}

A Northern Ryukyuan branch can be established on the basis of an important grammatical irregularity, namely the voicing of the consonant in the converb/ medial stem and related forms of the verb 'go'. ${ }^{6}$ The irregular voicing * $t>d$ of the initial consonant of 'bamboo' also defines Northern Ryukyuan as a branch (Table 1.1).

Table 1.1: Northern Ryukyuan innovations

\begin{tabular}{|c|c|c|c|}
\hline & & 'go' (converb) & 'bamboo' \\
\hline \multirow{6}{*}{ A } & Yamatohama & Pidzi & d9xэ \\
\hline & Shodon & Pìdzî & díxǒ \\
\hline & Kamikatetsu & Pidzi & dě: \\
\hline & Kametsu & Pìdzí & dó: \\
\hline & Wadomari & Pìdz-án & dé: \\
\hline & Yoron & idzi & dàì \\
\hline \multirow{3}{*}{$\mathrm{O}$} & Iejima & Pidzi & dákí \\
\hline & Nakijin & Pìdzí & dàkí: \\
\hline & Shuri & $n^{2} d z i$ & dákì \\
\hline M & Nishihara & itsi, iki: & taki \\
\hline $\mathrm{Y}$ & Ishigaki & iki, ikitte & tákì \\
\hline \multicolumn{2}{|c|}{ Dunan } & ititi & $\mathrm{t}^{\mathrm{h}} \mathrm{agi}$ \\
\hline
\end{tabular}

Within Northern Ryukyuan, an Amami (Table 1.2) and an Okinawan (Table 1.3) subgroup can be identified on the basis of several mutually exclusive innovations, and there is no support for the Southern Amami-Northern Okinawan, or "Kunigami", hypothesis often seen in the literature (e.g. Uemura 1997, Karimata 1999). That hypothesis groups together dialects on the basis of their vowel system and of the patterns of lenition of ${ }^{*} p$ and/or *k, but these are probably areal features or parallel developments.

5. Conversely, the absence of a feature from Ryukyuan does not obligatorily imply it cannot be reconstructed in Proto-Japonic.

6. According to Hattori (1955), this is a case of suppletism, with the converb/medial verb formed not on *ik- 'go' but on the distinct verb *in- 'leave'. The Miyako (Nishihara) and Yaeyama (Ishigaki) verb forms do not strictly correspond to the Northern Ryukyuan forms, but nevertheless, neither the old converb nor the newer form involves any irregularity. 
The Amami subgroup includes Yoron and all varieties located to its north. It is defined by the irregular vowel shift * $\mathrm{u}>\mathrm{a}$ in PR *kakozu C 'jaw' and a unique form for 'dust' instead of PJ * $\mathrm{p}[\mathrm{o} \mid \partial] \mathrm{k}[\mathrm{o} \mid ə]$ ri 3.1 (Table 1.2; Lawrence 2006 and p.c. 2009).

Table 1.2: Amami innovations

\begin{tabular}{|c|c|c|c|}
\hline & & 'jaw' & 'dust' \\
\hline \multirow{6}{*}{ A } & Yamatohama & $\mathrm{k}^{\mathrm{h}} \mathrm{axadz \dot {i }}$ & $\phi u \phi u \eta$ \\
\hline & Shodon & kháxăt & 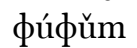 \\
\hline & Kamikatetsu & $\mathrm{k}^{\mathrm{h}} \mathrm{a}$ du ('talkative') & $\phi \hat{u}: m u ́$ \\
\hline & Kametsu & kâ:dzì & hó:mûy \\
\hline & Wadomari & kà:dzí & \\
\hline & Yoron & ká:dzí & pùzmú \\
\hline \multirow{3}{*}{$\mathrm{O}$} & Iejima & hákúzì & $\mathrm{p}^{\mathrm{h}}$ ưkúì \\
\hline & Nakijin & hàkù:dzó & pù̀kúí \\
\hline & Shuri & kákúdzí & 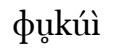 \\
\hline $\mathrm{M}$ & Ōgami & kamaks & puki \\
\hline $\mathrm{Y}$ & Ishigaki & kakúdzí & фúkúì \\
\hline \multicolumn{2}{|c|}{ Dunan } & kª̀gúdî & $k^{2}$ ùy \\
\hline
\end{tabular}

On the other hand, the Okinawan subgroup (Table 1.3) is defined by the irregular lengthening of the first vowel in $\mathrm{PR}$ *kame $\mathrm{B}<\mathrm{PJ}$ *kamai 2.3a 'turtle', the irregular change *a $>$ o in PR *pato B $<$ PJ *pato 2.3b 'pigeon' (Lawrence 2006), and a semantic shift 'disgusting, distasteful' > 'dirty' for PR *pago B (Pellard 2009: 249-275).

Table 1.3: Okinawan innovations

\begin{tabular}{|c|c|c|c|c|}
\hline & & 'turtle' & 'pigeon' & 'dirty' \\
\hline \multirow{6}{*}{$\mathrm{O}$} & Izena & ha:mi & фustu & hagusay \\
\hline & Iejima & há:mí & $\mathrm{p}^{\mathrm{h}}$ óttú & phágósà \\
\hline & Sesoko & hà:mí & hò:tú & hògòcéy \\
\hline & Nakijin & hà:mí: & pò:tú: & pàgò:6êy \\
\hline & Shuri & ká:mí: & hó:tú & hágó:sán \\
\hline & Kume & ka:mi: & ho:tu & hago:sa: \\
\hline \multirow{3}{*}{ A } & Shodon & $\mathrm{k}^{\mathrm{h}}$ ámı̌ & hát ${ }^{\text {tǒ }}$ & janagэsam \\
\hline & Wadomari & hàmı̌: & фà:tǔz & n’jázcây \\
\hline & Yoron & hàmí & pàtú & jànàgísày \\
\hline $\bar{M}$ & Ōgami & kami & m:patuu & skatakam \\
\hline $\mathrm{Y}$ & Ishigaki & kàmí & pátú & jàníc6á:y \\
\hline \multicolumn{2}{|c|}{ Dunan } & khàmì & hàtû & dìnây \\
\hline
\end{tabular}




\subsubsection{Southern Ryukyuan}

The Southern Ryukyuan branch encompasses all varieties spoken in the Sakishima Islands, namely Miyako, Yaeyama, and Dunan. It is defined by innovations such as the irregular shift from tone class B to A for 'how many' (Lawrence 2008), a special form for 'garden' (Pellard 2009: 249-275), and an irregular vowel shift * $\mathrm{i}>\mathrm{u}(>\varnothing)$ in $\mathrm{PR}$ *pitae A $<$ PJ pitape 3.1 ' forehead'7 (Table 1.4).

Table 1.4: Southern Ryukyuan innovations

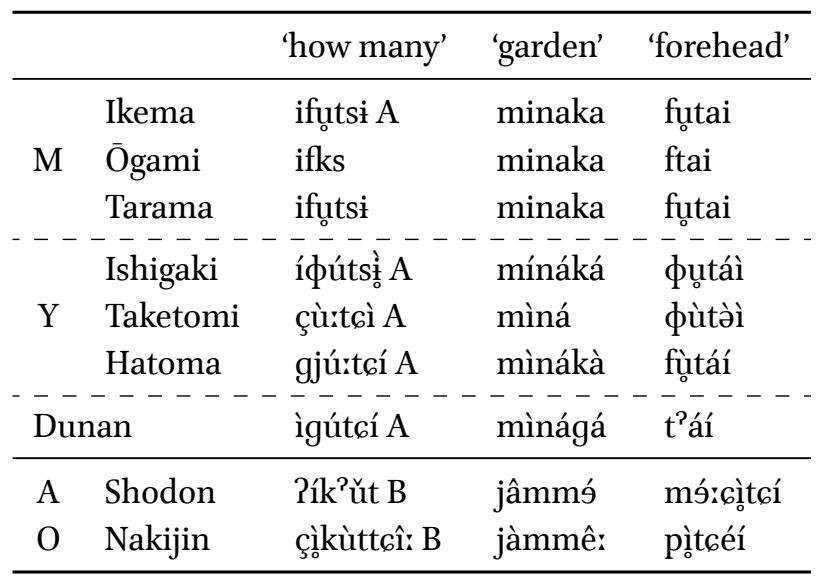

Within Southern Ryukyuan, a Miyako subgroup can be distinguished on the basis of several Proto-Miyako innovations (Table 1.5), such as the inclusive marker, 'head' (Pellard 2009: 249-275), 'round', and 'get wet' (Lawrence 2003). On this basis, it is clear the Tarama dialect belongs to the Miyako subgroup and not the (Macro-)Yaeyama one, contra Karimata (2000). ${ }^{8}$

Table 1.5: Miyako innovations

\begin{tabular}{|c|c|c|c|c|c|}
\hline & & 'incl.' & 'head' & 'round' & 'get wet' \\
\hline \multirow{4}{*}{ M } & Ikema & mai & kanamai & ma:ku & mmi: \\
\hline & Nagahama & mai & kanamal & ma:ku & mmil \\
\hline & Ōgami & mai & kanamau & ma:ku & $\mathrm{mmi}$ \\
\hline & Tarama & mai & kanamal & marku & mmil \\
\hline $\mathrm{Y}$ & Ishigaki & $\eta$ & tsábúrí & múrúsà:y & dzóффìn \\
\hline \multicolumn{2}{|c|}{ Dunan } & $\eta$ & mìmbùrù & màrúykâ & j̀gárún \\
\hline A & Shodon & $\mathrm{m}$ & khámǎtc & marsa & nùrît $\mathrm{t}^{\mathrm{h}} \mathbf{x}$ \\
\hline $\mathrm{O}$ & Nakijin & $\eta$ & t6 ${ }^{’} \mathrm{ìmbú}$ & màrùcên & dírsûy \\
\hline
\end{tabular}

7. The Dunan form could come from either *putae or *pitae.

8. Though Lawrence (2003) considers Tarama to belong to the main Miyako branch, the fact it does not share several innovations seen in all other Miyako dialects (e.g., *-(s)amar- 'honorific', * $\mathrm{b}>$ * $\mathrm{g}$ in 'knee', etc.) shows Tarama constitutes a primary branch on its own within the Miyako subgroup (Pellard 2009: 280-283). 
A Macro-Yaeyama subgroup that comprises Yaeyama proper and Dunan is defined by the grammaticalization of 'know' as a potential auxiliary, special forms for 'bud' (Lawrence 2000), 'happy', 'fresh', and 'dirt', and the semantic extension of 'nephew' to 'nephew or niece' (Pellard 2009: 249-275). Though Dunan is sometimes classified as a primary branch of Ryukyuan (Kokuritsu kokugo kenkyūjo 1963, Thorpe 1983) or of Southern Ryukyuan (Hirayama 1992-1994, Uemura 1997, Karimata 1999, Bentley 2008), its close relationship with Yaeyama is beyond doubt.

Table 1.6: Macro-Yaeyama innovations

\begin{tabular}{|c|c|c|c|c|c|c|}
\hline & 'potential' & 'bud' & 'happy' & 'niece' & 'dirt’ & 'fresh' \\
\hline Ishigaki & 66in & báí & sánìcà:y & búì(-фà:) & gábá & pírágícá:y \\
\hline Y Taketomi & s6un & bəi & sənisəy & bùì-фà: & gàbá & pírcèsàn \\
\hline Y Hatoma & $66 \mathrm{e}: y$ & bàì & sàníjày & bùì & gàbà: & pìrákèn \\
\hline Hateruma & 66ay & bë: & sanicahay & bui & gaba & pirissahay \\
\hline Dunan & tsºúy & bai & sànáy & búíhá & gaba & çiragjay \\
\hline Ikema & & $\mathrm{mi}:$ & hưkarasiskai & mjusi & fussi & çigurukai \\
\hline M Ōgami & juis & $\mathrm{mil}$ & pukaraskam & miuu & napa & pukurukam \\
\hline Tarama & & fuki & pukaraca:l & mjuit & naba & pigullal \\
\hline A Shodon & & mǒ: & Puhoraca & mîkk ${ }^{2}$ wá & çîg.rú & sidaca \\
\hline O Nakijin & Pússûy & mìdùrí & фù̀kùrácèn & mìvúì & píngù & cìdà:cên \\
\hline
\end{tabular}

The Nuclear Yaeyama subgroup differs from Dunan in that it shares a causative form of 'buy' that replaced the original verb 'sell', a special form for 'get wet' (Pellard 2009: 249-275), and an irregular shift " $\mathrm{g}>n$ in PR *pige A 'beard' $<\mathrm{PJ}$ *piNkai 2.1.

Table 1.7: Yaeyama innovations

\begin{tabular}{|c|c|c|c|c|}
\hline & & 'sell' & 'get wet' & 'beard' \\
\hline \multirow{6}{*}{$\mathrm{Y}$} & Ishigaki & kâ:s̀̀n & dzó:rìn & pínì \\
\hline & Taketomi & kà:sùy & zurisuy & pìnì \\
\hline & Kuroshima & ha:suy & & pini \\
\hline & Hoshidate & ka:su & zo:risu & pini \\
\hline & Hatoma & ká:súy & dzó:rún & pìní \\
\hline & Hateruma & kasimimiruy & durisuy & pini \\
\hline \multicolumn{2}{|c|}{ Dunan } & ùrúy & ìgárún & ท̀gí \\
\hline M & Ōgami & v: & $\mathrm{mmi}$ & puki \\
\hline A & Shodon & Pùrjûm & nùrît $\mathrm{t}^{\mathrm{h}} \mathbf{x}$ & çìgî \\
\hline $\mathrm{O}$ & Nakijin & Púy & dírcûy & p’ìdzí: \\
\hline
\end{tabular}




\section{When did Ryukyuan and Japanese separate?}

Estimating when Ryukyuan and Japanese separated poses methodological problems. While it is common practice to give dates in archaeology and biology, by using carbon dating or the molecular clock, absolute chronological estimates are still controversial in linguistics.

\subsection{Dating methods}

In the case of Ryukyuan and Japanese, previous scholarship traditionally relied on the very controversial ${ }^{9}$ method of glottochronology. This method assumes words change at a universal fixed rate and measures the number of basic words shared between related languages in order to estimate when they separated. Several different formulas exist, and each of them give a different date for the split of Ryukyuan and Japanese, such as 500 CE (Hattori 1959: 80-83), 587 CE (Ōshiro 1972), or 996 CE (Unger 2009: 100).

More recently, following the trend initiated by Gray \& Atkinson (2003) for Indo-European, Lee \& Hasegawa (2011) applied a more sophisticated statistical method and estimated Ryukyuan and Japanese split around the $2^{\text {nd }}$ century BCE. However, this novel methodology is still subject to debate, ${ }^{10}$ and in this case there are problems with both the data and the application of the method (cognacy assessment, chronological calibration, etc.). ${ }^{11}$ If the new Yayoi chronology is correct and the beginnings of agriculture must be pushed back to around 950 BCE, ${ }^{12}$ the 8 oo-year gap with Lee \& Hasegawa's date then needs to be explained, and the correlation with archaeology does not hold anymore. ${ }^{13}$

Leaving aside these new promising methods until the dust settles, it is possible in the case of Ryukyuan and Japanese to use less controversial methods. For instance, if we can show that some changes attested in the Japanese written records of a certain period did not affect Ryukyuan, then Ryukyuan and Japanese must have split before that time. Though this method does not allow to determine a precise date or even a terminus post quem, it will give a solid estimate of the latest possible date for this split.

\subsection{Archaic features in Ryukyuan}

Though some scholars (e.g., Yanagida 1993) argue that the separation of Ryukyuan and Japanese dates from the (early?) Late Middle Japanese (LMJ) period (13th-15th century CE), this hypothesis not only lacks support from archaeology

9. See Bergsland \& Vogt (1962), Blust (2000)

10. See the discussions collected in Forster \& Renfrew (2006).

11. In particular, the position assigned to Hachijō is dubious, as well as the subgroupings of the Japanese dialects. Moreover, the fact no time calibration at all is offered for the Ryukyuan branch is problematic.

12. See the discussion in Shōda (2007).

13. The conclusion by Lee \& Hasegawa (2011) that Japonic did not enter Japan during the Jōmon period but with the spread of agriculture during the Yayoi period is not controversial in itself and seems more than likely (see Hattori 1959, Hudson 1994, Unger 20o9, Whitman 2012). 
(subsection 5.1), it is also irreconcilable with many linguistic facts which clearly point to an earlier date.

First, the syllables $e$ and $j e$ merged around the first half of the 1oth century in Japanese (Mabuchi 1994: 48-53, Frellesvig 2010: 206), but for example the distinction between the initial syllable of Early Middle Japanese (EMJ, 9th-12th century CE) ebi 'shrimp' and $y e$ 'handle' is preserved in Northern Ryukyuan: Shodon Pîp vs. jî̀, Kamikatetsu ibi vs. ǰ̌r, Izena Pibi vs. jii. The split between Ryukyuan and Japanese cannot thus have happened later than the 1oth century.

Moreover, Ryukyuan preserves the phonological distinction between ProtoJaponic *ui and * ${ }^{*}$ i, which had already merged into $i_{2}$ by the $7 / 8$ th century in Japanese. That this distinction goes back to Proto-Japonic is confirmed by the fact that these diphthongs follow different alternation patterns in the morphophonology: $i_{2}<*$ ui alternates with $u$, and $i_{2}<{ }^{*}$ əi with $o_{(2)}$ in Old Japanese. For example, $t u k i_{2}$ 'moon' has an alternate stem tuku- (tuku-yo$o_{1}$ 'moon night'), while $k i_{2}$ 'tree' has a variant stem $k \mathrm{O}_{2}-\left(\mathrm{ko}_{2}-n \mathrm{o}_{2}-\mathrm{pa}\right.$ 'tree leaf') in Old Japanese, and these two $k i_{2}$ have distinct reflexes in Ryukyuan (Table 1.8).

Table 1.8: Pre-Old Japanese distinctions preserved in Ryukyuan

\begin{tabular}{|c|c|c|}
\hline & 'moon' & 'tree' \\
\hline PJ & *tukui $2.3 \mathrm{~b}$ & *kəi 1.3a \\
\hline $\mathrm{OJ}$ & $t u k i_{2} \sim t u k u-$ & $k i_{2} \sim k o_{2}-$ \\
\hline PR & *tuki B & *kee B \\
\hline Shodon & $\mathrm{t}^{\mathrm{h}} \mathfrak{\mathrm { j }}_{\mathrm{o}} \mathrm{k}^{? \mathrm{v}}$ & $\mathrm{k}^{\mathrm{h} \check{\mathbf{Y}} \mathrm{z}}$ \\
\hline Nakijin & Gìtcȟ: & kǐ: \\
\hline Ōgami & ksks & ki: \\
\hline Ishigaki & tsịkí & kí: \\
\hline Dunan & $t^{?}{ }_{1:}$ & $\mathrm{k}^{\mathrm{h}} \mathrm{i} \mathrm{z}$ \\
\hline
\end{tabular}

Comparative studies of Japanese and Ryukyuan have shown that Ryukyuan also preserves several other phonological distinctions lost in Old Japanese. Thus, while PJ ${ }^{*} \mathrm{i}$ and ${ }^{*} \mathrm{e}$, as well as *o and ${ }^{*} \mathrm{u}$, had already merged in many environments in Old Japanese, they are distinct in Proto-Ryukyuan (Hattori 1978-1979, Thorpe 1983, Serafim 2008, Pellard 2008, 2009, 2013; Table 1.9).

Table 1.9: PJ *i vs. *e and *u vs *o

\begin{tabular}{|c|c|c|c|c|}
\hline & 'daytime' & 'garlic' & 'mortar' & 'medicine' \\
\hline PJ & *piru 2.2 & *peru 2.1 & ${ }^{*}[\mathrm{u} / \mathrm{o}] \mathrm{su} 2.5 \mathrm{a}$ & ${ }^{*}$ kusori $3.7 \mathrm{a}$ \\
\hline OJ & $p i_{1} r u$ & $p i_{1} r u$ & usu & kusuri \\
\hline PR & *piru A & *peru A & $*[\mathrm{u} / \mathrm{o}] \mathrm{su} \mathrm{C}$ & *kusori C \\
\hline Shodon & çî & $\phi \hat{\mathfrak{t}} \mathrm{r}$ & Púsǔ & 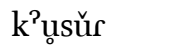 \\
\hline Nakijin & p’ìrú: & $\mathrm{p}^{\text {hìrú: }}$ & Púcì & kùsùí \\
\hline Ōgami & psi-ma & piu & us & ffum \\
\hline Ishigaki & p̂̂yxì & pîn & úsí & фuccírí \\
\hline Dunan & ts'ú: & çiru & ùt6̂̂ & ts’̀̀û̂ \\
\hline
\end{tabular}


Several mergers that occurred in Old and Middle Japanese are not found in Ryukyuan, so the only logical conclusion is that Ryukyuan is not a daughter language of Old Japanese but that the two are sister languages that separated before the 7 th century.

\subsection{Later Japanese-Ryukyuan contacts}

Though Ryukyuan exhibits many archaic features that can only be explained if we assume it split from Japanese before the 7 th century, it also shows traces of later contacts with Japanese. For instance, a fair number of Sino-Japanese loanwords are found in the Ryukyuan languages, but many of them exhibit irregular correspondences and exist only in Okinawan. They are thus probably late loans due to contacts between the Ryukyu kingdom and Japan. On the other hand, some Sino-Japanese loans are found not only in Northern Ryukyuan, but also in Southern Ryukyuan, in an area traditionally more isolated, and they can be reconstructed for Proto-Ryukyuan. Moreover, these show clear Sino-Japanese features and are thus not direct borrowings from Chinese either.

Particularly telling is the case of words with ${ }^{*} \mathrm{a}(\mathrm{j} / \mathrm{i} / \mathrm{w}) \mathrm{n}$-ending rhymes in Early Middle Chinese (EMC), which were borrowed with aũ-endings in Early Middle Japanese and have cognates with au-finals in Miyako (Table 1.10). These Sino-Japanese words must have been borrowed from Japanese sometime between the 8/9th century, when Sino-Japanese words started to be massively borrowed in Japanese, and the 13/15th century, when au underwent monophtongization to s: in Japanese (Mabuchi 1994: 115-118, Frellesvig 2010: 319-321).

Table 1.10: Sino-Japanese loans in Ryukyuan

\begin{tabular}{|c|c|c|c|}
\hline & $\begin{array}{c}\text { 'stick’ } \\
\text { 棒 }\end{array}$ & $\begin{array}{l}\text { '1 }{ }^{\text {st }} \text { month' } \\
\text { 正月 }\end{array}$ & $\begin{array}{c}\text { 'skillful' } \\
\text { 上手 }\end{array}$ \\
\hline EMC & baiwn ${ }^{h}$ & tciajy yuat & dzian cuw' \\
\hline EMJ & baũ & syaügwat & zyaũzu \\
\hline LMJ & bo: & syorgwat & zуэ:zи \\
\hline A Shodon & bô: & có:gwàddł̂k & dzǒt \\
\hline O Shuri & bó: & có:gwátsí & dzó:dzí \\
\hline M Ōgami & pau & saukaks & tauku \\
\hline Y Ishigaki & bó: & 6óygwàdzì & dzó:dzí \\
\hline Dunan & bû: & sùyátî & dudi \\
\hline PR & *bau C & *sjaugwatu C & ${ }^{*} z j a u z u$ B/C \\
\hline
\end{tabular}

We can thus conclude that after it separated from Japanese sometime before the 7 th century, (pre-)Proto-Ryukyuan was in contact with Early Middle Japanese for several centuries, until at least the $8 / 9$ th century and at most the late 13 th century. 


\section{Diversity and change}

Linguistic substratum and language/dialect mixing are popular theories in Japanese linguistics, and the cline of linguistic diversity that culminates in the Yaeyama region is often attributed to the effect of contact with preexisting languages (Uemura 1997, Serafim 1994). In particular, Serafim (1994) hypothesizes that there was a linear expansion through the Ryukyus, where each move added contact with the language(s) of preexisting inhabitants and thus a layer of linguistic changes due to a substratum effect. But this is actually contradicted by direct evidence from linguistics (section 4), archaeology, and anthropology (section 5).

Moreover, purely internal explanations are able to account for the Ryukyuan diversity. First, insular geography favors isolation and thus divergence by triggering punctuational bursts (Atkinson, Meade, et al. 2008): colonization of new locations by small groups constitutes founder effects that cause rapid changes. This leads in turn to the appearance of new linguistic varieties potentially highly divergent from their parent. ${ }^{14}$ In the case of archipelagos of small islands, these effects are of course multiplied.

Not only is there no need to suppose the existence of any substratum in Ryukyuan, there is actually no direct evidence for it. In particular, no convincing linguistic comparison between Austronesian and Ryukyuan has been presented as yet (Pellard 2009: 19-20; Lawrence, this volume).

\section{Inferring prehistory from language}

Considering the above phylogeny of the Japonic languages and the evidence about the timing of their interactions, it is possible to draw some hypotheses about the speakers, as well as about their society.

\subsection{Homeland}

A widespread idea in historical linguistics is that the zone of maximum diversity of a language family is its most likely homeland (Sapir 1916: 79-83, Nichols 1997). In the case of Japonic, it would imply the Southern Ryukyus are the homeland from which both Ryukyuan and Japanese expanded. However, such a hypothesis is in total contradiction with what we know about archaeology (section 5), and more crucially, it is at odds with the linguistic facts. The evidence from Sino-Japanese loanwords in Proto-Ryukyuan implies prolonged contacts with Japanese, and it thus seems likely the two of them were at that time located in geographically close areas. The idea that the early Sino-Japanese loans were borrowed after the settlement of the Ryukyus implies that close contacts could have been maintained in spite of the distance and that those were borrowed all at once during the short time frame between the arrival of Proto-Ryukyuan in

14. Compare with the observation of accelerated evolution in organisms living on islands (Millien 2006). 
the islands and its expansion and diversification. Such a scenario seems rather unlikely.

Kyushu, the closest Japanese large island, immediately comes to mind as a likely homeland, and Serafim (2003) pointed out some similarities between Ryukyuan and some Japanese dialects of Kyushu, which could suggest the existence of a Ryukyuan substratum there. However, the evidence remains rather scarce, and it remains unknown whether these are not just shared retentions or parallel developments.

\subsection{Migration and diversification}

The phylogenetic tree of the Ryukyuan languages (Figure 1.1) represents a sequence of evolutionary changes, and its shape gives us a relative chronology of the separation of the different languages. If we lay out this tree on a geographical map, it is possible to associate the nodes and branches of the tree with migration moves.

First of all, since all Ryukyuan languages form a single branch, we can infer the settlement of the Ryukyus was not achieved by different waves of migration at different periods and from different places, but probably by one or a few moves from a single area, and within a rather narrow time frame.

The general topology of the tree also indicates the closest islands were not always colonized first. ${ }^{15}$ If every island encountered had been settled as the ProtoRyukyuans advanced straight ahead in the archipelago, each island would be associated with a bifurcation on the main branch, and there would be no Northern Ryukyuan, Amami, nor Okinawan subgroup. However, the Southern Ryukyuan languages form a sister branch of Northern Ryukyuan as a whole, and not just Okinawan. If the settlement of the Ryukyus had taken place in a linear fashion from north to south, we would find innovations shared by Okinawan and Southern Ryukyuan but not by Amami, and no innovation shared by Amami and Okinawan but not by Southern Ryukyuan. This is the exact reverse of the actual situation. On the other hand, the inner branching of Southern Ryukyuan is compatible with a north-to-south expansion: Miyako is settled first, then Yaeyama, with the too small Tarama Island bypassed, and finally Yonaguni.

Several scenarios ${ }^{16}$ can be proposed to account for this tree topology. First, the Southern Ryukyus might have been settled independently of the north, directly from Mainland Japan (probably Kyushu). This implies two distinct migration waves, though there is no need to suppose any particular chronological order, or even that one wave happened after the other. ${ }^{17}$

Second, there could have been a single move out of Japan, that reached either Okinawa or Amami first. Then, a subset of these settlers would have left for

15. This is congruent with the typology of island colonization by Keegan \& Diamond (1987). 16. I won't consider the hypothesis that the Northern Ryukyus may have been settled from the Sakishima for the reasons exposed in section 5 .

17. I leave out the possibility these two waves were just one that split into two on the way to the Ryukyus. 
the south, separating from those who thereby became the Proto-Northern Ryukyuans. This supposes either the first wave bypassed Amami and went straight to Okinawa, or that the second wave toward the Southern Ryukyus started from Amami and bypassed Okinawa. This hypothesis implies either Amami or Okinawa was not settled before the Sakishima.

Yet another hypothesis is possible, which supposes language replacement happened in either Amami or Okinawa. The Ryukyus could have been indeed settled progressively from north to south, but later either Amami or Okinawan intruded beyond its original area and replaced preexisting varieties of Northern Ryukyuan there. This language shift would have occurred before the diversification of the intruding language.

\subsection{Linguistic palaeontology}

Following the idea language reflects the culture of the people who use it, we can assume that if a word for a particular object can be reconstructed in a protolanguage, that object was probably part of the culture of the speakers. Applying such a method of linguistic palaeontology, it is possible to hypothesize that the Proto-Ryukyuan speakers were most probably farmers familiar with rice agriculture, pottery, and navigation. This is supported by the existence of a common set of vocabulary pertaining to agriculture, ${ }^{18}$ livestock, pottery, and sailing in Proto-Ryukyuan (Table 1.11).

\section{Toward a new synthesis}

The window opened on the Ryukyuan past by historical linguistics is only a partial one. In particular, the problem of absolute dating cannot be solved with confidence, though it is possible to provide a time frame. Other inferences made on the basis of linguistics also need to be complemented by and checked against the results of archaeology and anthropology, in order to write a holistic scenario.

\subsection{Archaeology}

The earliest human remains in the Japan-Ryukyu region are found in the Ryukyus, in the Yamashita-chō cave of Okinawa, and date from 32,ooo years ago. However, these ancient populations do not seem to have survived the Palaeolithic, and they are thus not related to the modern Ryukyuan people (Asato \& Doi 1999, Takamiya 2005: 95-100).

Following the Palaeolithic, the Shellmound period of the Northern Ryukyus (6400 BP-11th century $\mathrm{CE}$ ) hosted a hunter-gatherer culture roughly similar to the Jōmon culture of Mainland Japan. From the Middle Shellmound period on, the Northern Ryukyus were in contact with Japan via Kyushu through a trade

18. There is however variation in the diversity of rice vocabulary within Ryukyuan. This suggests rice agriculture was not evenly practiced and had not the same importance everywhere. 
Table 1.11: Ryukyuan cultural lexicon

\begin{tabular}{|c|c|c|c|c|c|c|}
\hline & PR & Shodon & Shuri & Ōgami & Ishigaki & Dunan \\
\hline 'rice' & *kome B & $\mathrm{k}^{\mathrm{h}}$ úmŭ & kúmí & & & \\
\hline 'rice' & *mai A & & mê: & mau & máì & màí \\
\hline 'rice plant' & *ine B & Pínǐ & ñ?ní & & íní & ǹnì \\
\hline 'unhulled rice' & ${ }^{*}$ momi A & mûm & múmì & & & mumi \\
\hline 'wheat' & *mogi B & múgǐ & múzí & muku & mún & mùy \\
\hline 'foxtail millet' & *awa B & Pǒ: & Páwá & a: & á: & à: \\
\hline 'broomcorn millet' & ${ }^{*}$ kimi B & k’ímǐ & mâ:-zìn & kum & kín & t $6^{2}$ in-ti \\
\hline 'taro, yam' & *umo B & Púmǔ & ḿ$^{2} m u ́$ & $\mathrm{m:}$ & úy & ùn-tî \\
\hline 'field' & *patake C & xàt9̂xó & hátákí & & pàtágí & hàtágî \\
\hline 'rice paddy' & ${ }^{*}$ ta B & thă: & tá: & ta: & tá: & $\mathrm{t}^{\mathrm{h}}$ à: \\
\hline 'cow' & *usi A & Pû́ & Púcì & us & úsì & ùtcí \\
\hline 'pig' & *uwa C & $w^{2}$ ă: & w?á: & va: & ó: & wà: \\
\hline 'horse' & *uma B & Púmǎ & 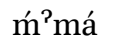 & nu:ma & ḿmá & m̀mmà \\
\hline 'pot' & *tubo A & $t^{P} \grave{t} b \hat{u}$ & tsíbù & kupu & tsábù & t6’ìbú \\
\hline 'jar’ & *kame C & 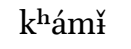 & ká:mí & kami & kàmí & $\mathrm{k}^{\mathrm{h}} \mathrm{ami}$ \\
\hline 'boat' & *pune C & фúnř & фúní & funi & фúní & ǹnî \\
\hline 'sail' & *po A & $\phi \hat{u}:$ & $\phi \hat{u ̂}:$ & & pû: & hú: \\
\hline 'paddle' & *ijako B & júhǒ & Ré:kú & uaku & jákú & dàyù \\
\hline
\end{tabular}

network that provided them with pottery, and perhaps rice, in exchange of seashells used in ornaments (Asato \& Doi 1999, Asato, Takara, et al. 2004). However, neither the Yayoi culture (950/500 BCE-300 CE) nor the following Kofun culture $\left(3^{\text {rd }}\right.$-6th century CE) expanded into the Ryukyus (Asato \& Doi 1999, Asato, Takara, et al. 2004, Pearson 2001). Despite being in contact with the Yayoi agriculturalists, the Shellmound foragers did not shift to agriculture, even though they underwent a food stress crisis. Their population was probably not very large, as islands cannot sustain a large number of foragers, and most of the islands were thus probably uninhabited (Takamiya 2005: 57-60).

In the meanwhile, the Southern Ryukyus formed a separate area isolated from the North until the 11/12th century No traces are found of the Jōmon and Yayoi cultures, but an Austronesian colonization from Taiwan around 4500 BP can be identified in the Shimotabaru pottery of Yaeyama (Summerhayes \& Anderson 2009). However, this Austronesian colony did not last and, after a blank of several centuries, it was followed until the 11/12th century CE by a culture which did not make use of pottery and did not practice agriculture (Asato \& Doi 1999, Asato, Takara, et al. 2004).

It is only at the end of the Late Shellmound period that agriculture developed in the Ryukyus, around the 10/11th c (Takamiya 2005: 144-172), with rice as the main crop and other cereals (wheat, barley, foxtail millet) as supplements. This mixed agriculture corresponds to that practiced in Mainland Japan at that time (Kinoshita 2003). The transition from foraging to agriculture was abrupt, 
accompanied with a sudden demographic explosion in all the Ryukyus and particularly in Southern Okinawa, and it is not explainable by a simple scenario of shift to agriculture by the existing foragers (Asato \& Doi 1999: 88-91, Takamiya 2005: 174-179). The exact status of the recently discovered archeological site of the Gusuku village on Kikai Island remains to be determined, but it seems to have served as a major trade center with Japan between the gth and 13 th CE. ${ }^{19}$ It thus could have played a major role in the settlement of the Ryukyus by Japonic speakers.

This Proto-Gusuku period (Asato \& Doi 1999, Asato, Takara, et al. 2004) laid in a few centuries (10-12th century) the bases of a hierarchical society based on farming, metallurgy, and trade. It led to the development of competitive polities in Okinawa, and later to the rise of the Ryukyu kingdom. Moreover, for the first time the isolation of the Sakishima was broken, and roughly the same culture as in the North developed there. There is evidence that the Yamato State of Japan knew of the existence of the Ryukyus, and some of its embassies to China called at Ryukyuan islands on their way to the continent (Kinoshita 2003). The contacts intensified with the start of the Proto-Gusuku period, and a trade network developed between the Ryukyus and Japan, ultimately extending to China. The main trade goods were soapstone cauldrons from Nagasaki in Kyushu, iron from Kyushu, Chinese porcelain, Ryukyuan sulfur, and Ryukyuan seashells used in lacquer-ware ornaments. In parallel, kamui-yaki stoneware from Tokunoshima in the Amami region diffused throughout all the Ryukyus, where it was probably used to stock grains, and a new type of "Gusuku" ceramics appeared (Asato \& Doi 1999, Asato, Takara, et al. 2004, Pearson 2001).

Several scenarios have been proposed to account for these facts, which differ on details but tell more or less the same story. Asato (Asato \& Doi 1999, Asato, Takara, et al. 2004) sets the start of the Proto-Gusuku period rather early (1oth century) and thinks there was a temporal sequence of events, starting from the diffusion of Nagasaki cauldrons, followed by that of kamui-yaki ware, and then of agriculture. He also stresses the importance of a group of traders from the Ryukyus who diffused the kamui-yaki ware throughout the Ryukyus from the 11th century on. On the other hand, Kinoshita (2003) thinks all happened within a short and later time frame and was the deed of Japanese merchants from Fukuoka motivated by a rise in price of the seashells from the Ryukyus. Both remain vague about who the Japanese merchants traded with, and who colonized and developed agriculture in the Ryukyus. We can infer the settlers must have been a group of Japanese, comprising traders, craftsmen and farmers, who were transported there along the road of the seashell trade.

\subsection{Anthropology}

Recent studies of both ancient and modern DNA (Li et al. 2006, Shinoda \& Doi 2008, Matsukusa et al. 2010) tend to show that Ryukyuans form a group closely related to the Mainland Japanese, and only more distantly to the Jōmon and Ainu

19. See Takanashi et al. (2009) and references therein. 
(Tajima et al. 2004). Despite their geographical proximity, Southern Ryukyuans do not show any particular affinity with the Austronesian populations of Taiwan, and they form a clear subgroup with Northern Ryukyuans (Li et al. 2006, Shinoda \& Doi 2008, Matsukusa et al. 2010). However, Southern Ryukyuans do not form a cluster within that subgroup, and the position of Amami Islanders remains to be determined. Genetic diversity is not particularly high in the Ryukyus, which suggests neither long-term isolation nor population size reduction. There is also evidence for sex-biased migrations, with a higher rate of geographic isolation in males than in females (Matsukusa et al. 2010).

The results of different dental and cranial studies are contradictory, and there seems to be no consensus on the question of whether there is a connection between Ryukyuans and the Jōmon people or the Ainu. Ryukyuans appear however to be generally close to (near-)Modern Mainland Japanese. Dental analyses also reveal high inter-island diversity within the Ryukyus. ${ }^{20}$

All of this suggests that both Northern and Southern Ryukyuans descend from a population influx from Mainland Japan after the beginning of the Yayoi period that simply replaced any preexisting inhabitants without significant admixture with them. The fact Southern Ryukyuans are genetically close to Northern Ryukyuans, although these two regions previously hosted distinct populations, suggests Ryukyuan did not enter the area by pure diffusion to preexisting populations but was brought there by a migration wave that replaced earlier inhabitants, contra Serafim (1994).

\subsection{A unified scenario}

At least three scenarios of the settlement of the Ryukyus and the spread of the Japonic civilization there have been proposed: the "Ocean Road", the "Hayato", and the "Proto-Gusuku" scenario.

According to the Ocean Road hypothesis, a scenario originally proposed by the Japanese ethnographer Yanagita (1952), wet rice agriculture was introduced from China in the Southern Ryukyus first, and then was transmitted to Okinawa and finally to Japan. While not concerned by this issue in particular, it suggests an early settlement of the Ryukyus by Japonic agriculturalists before the Yayoi period. However, such a scenario is contradicted by archaeological evidence, as agriculture began earlier in Mainland Japan than in the Ryukyus (Takamiya 2001), and from a linguistic point of view, if Japonic had spread with agriculture from the south, the presence of Sino-Japanese loanwords in Southern Ryukyuan would not be expected.

The Hayato hypothesis associates the spread of Japonic in the Ryukyus with a migration before the 8th century CE of the Hayato "barbarians" of Kyushu depicted in the Old Japanese chronicles. The Hayato would have fled farther and farther South as they were repelled by the extending forces of the Yamato state (Uemura 1997, Serafim 1994). Glottochronological evidence played a major role

20. See Asato \& Doi (1999), Pietrusewsky (1999), Haneji et al. (2007), Toma et al. (2007) and references therein. 
in this scenario, as it was accepted the Ryukyuan-Japanese split happened before or around the Kofun period ( $3^{\text {rd }}-6$ th century CE) and that the settlement of the Ryukyus would have occurred around that time too. However, no evidence is found for such a migration at that time, and the evidence from loanwords suggests Ryukyuan stayed in contact with Japanese until a much later date.

The Proto-Gusuku hypothesis (Asato \& Doi 1999, Takamiya 2005) convincingly argues that the only event which can be meaningfully associated with a Japonic expansion in the Ryukyus is the migration around the 1oth century that led to the formation of the Gusuku culture. Linguistic evidence was seen as irreconcilable ${ }^{21}$ with the other data, due to the reliance on the glottochronological calculations by Hattori (1959). But glottochronology, though very appealing to archaeologists, is a rather controversial tool, and the loanword evidence indicates that the ancestor of Ryukyuan was still spoken on the mainland until perhaps as late as the 12th century. There is thus no obstacle from linguistics to the Proto-Gusuku scenario, as already acknowledged by Serafim (2003), and the loanword evidence is actually congruent with it.

Refining the Proto-Gusuku hypothesis, we can say that the Ryukyuan languages form a sister branch of Japanese and that their ancestor separated from Japanese probably during the first centuries CE. This is likely to have happened at the end of the Yayoi period, just before the rise of the Kofun culture and the emergence of strong polities in Japan that led to the formation of the Yamato state in Central Japan, the homeland of Old Japanese..$^{22}$ If Ryukyuan and Japanese had split much earlier than that, such as around the beginning of the Yayoi period a millenium earlier, they would probably be much more divergent.

After that, (pre-)Proto-Ryukyuan was still spoken on the mainland, most likely in Kyushu, for several centuries. The socio-linguistic situation of Kyushu at that time is not known, but (pre-)Proto-Ryukyuan was influenced by Japanese, the extending language of the prominent Yamato state. The Ryukyus were known to the inhabitants of the mainland since Yayoi, thanks to a trade network. Then, around the 10/12th century, several millennia after the disappearance of the Austronesians from the Sakishima, a group of merchants from Kyushu, accompanied by craftsmen and farmers who settled there, entered the Ryukyus, down to the Sakishima, probably motivated by the rising market value of the Ryukyuan seashells.

The settlers gave birth to and diffused the Gusuku culture, a package comprising agriculture, ceramics, and the Proto-Ryukyuan language. If the Gusuku culture can indeed be associated with the Proto-Ryukyuan speakers, the fact it is found in the Southern Ryukyus but not on Kyushu leads to the conclusion that the current population of the Ryukyus is probably not the product of several migration waves from Japan. The Northern Ryukyus must have been settled first,

21. For instance Takamiya (2005: 196) believes he will trigger violent opposition from linguists when he concludes the colonization of the Ryukyus is most likely to have happened around the $10 / 12$ th century.

22. See Hattori (1959) for a similar idea about pre-Kofun as a likely archaeological setting for the Ryukyuan-Japanese split. On the Kofun period and state formation, see Barnes (2007). 
perhaps starting with Kikai Island, and the Gusuku culture evolved there before it was brought to the Southern Ryukus. The exact timing of this Southern expansion remains to be determined.

The bearers of the Gusuku culture expanded within the whole Ryukyu Archipelago, and preexisting foragers, who were few, simply died out or were assimilated without leaving a significant trace. The relative isolation of the different islands and the fact settlers probably formed small groups accelerated linguistic change, but contacts did exist between islands, and their populations intermarried. After Proto-Ryukyuan entered the Ryukyus, all its remaining relatives in Kyushu were slowly annihilated by the ongoing influence of Japanese, and no trace remains of them today.

\section{Conclusions and future prospects}

Trying to synthesize the results of historical linguistics, archaeology and anthropology has proven particularly fruitful in circumventing the lack of ancient written records and the low survival rate of organic remains in the Ryukyu Islands. Results all converge to tell the same story, that of a migration from Kyushu around the 10/12th century that replaced the preexisting inhabitants and founded the Gusuku culture.

Linguistic evidence plays here a key role in reconciling contradictory data, but the conclusion that the migration of Proto-Ryukyuan probably happened later than the split with Japanese itself was motivated by purely linguistic evidence, namely that of Sino-Japanese loanwords. The fact such an hypothesis independently formulated is congruent with other kinds of evidence only adds to its credibility. The proposed scenario also fits well with the Farming/Language Dispersal hypothesis (Bellwood \& Renfrew 2002): Proto-Ryukyuan managed to expand in the Ryukyus because its speakers were able to durably settle there, and this was possible only because they practiced agriculture.

Though the main line of the above scenario is rather clear, many details remain to be determined. For instance, when exactly did Proto-Ryukyuan split from Proto-Japanese and when did it move to the Ryukyus? Where in Kyushu did the settlers come from? Who were they actually? What role did the traders play in the colonization? When and how did language shift to Japanese happen in Kyushu? Such questions are still open for future research. Also, the exact chronology of the migration and of the spread of agriculture has not been sufficiently investigated.

Future research will need to clarify such details, to thoroughly evaluate the different hypotheses and to test how well the data matches the emerging scenario. ${ }^{23}$ For the time being, the scenario of the expansion Japonic in the Ryukyus presented here is no more than a plausible narrative, though a rather convincing one.

23. See Greenhill \& Gray (2005) for an interesting example of such an evaluation in the case of the Austronesian settlement of the Pacific. 


\section{Note on sources and transcriptions}

All Ryukyuan linguistic forms are given in a unified broad phonetic transcription following the conventions of the IPA. Tense ("glottalized") consonants are transcribed with a superscript glottal stop. Tones are left unmarked when I have no reliable information. The tone category $\mathrm{C}$ in Dunan is marked as final-falling, though it is actually realized nowadays as a high tone in the case of light syllables. The letters A, B and C correspond to the historical tonal categories first established by Hattori (1958, 1978-1979) and Matsumori (1998, 200oa,b). ProtoJaponic tone categories follow the notation of Martin (1987), with some additions.

The Ryukyuan and Japanese linguistic forms are cited from the following sources. Yamatohama: Osada \& Suyama (1977-1980); Shodon: personal field notes, Martin (1970), Karimata (1996); Kamikatetsu: personal field notes, Kibe et al. (2011), Shirata et al. (2011); Kametsu and Wadomari: Hirayama (1986); Yoron: Kiku \& Takahashi (2005); Izena: Uchima \& Aragaki (200o); Iejima: Oshio (1999); Sesoko: Hirayama (1992-1994); Nakijin: Nakasone (1983); Shuri: Kokuritsu kokugo kenkyūjo (1963); Kume: Uchima \& Aragaki (200o); Ōgami: personal field notes; Ikema, Nagahama and Tarama: Hirayama, Ōshima \& Nakamoto (1967), Hirayama (1983); Ishigaki: Miyagi (2003); Taketomi: Hirayama, Ōshima \& Nakamoto (1967), Maeara (2011); Hoshidate: Maeō (2002); Kuroshima: personal field notes; Hateruma: Hirayama, Ōshima \& Nakamoto (1967), Hirayama (1988), Aso (2010); Dunan: personal field notes, Ikema (2003), Uwano (2009); Japanese dialects: Hirayama (1992-1994). Proto-Ryukyuan and Proto-Japonic reconstructions are my own, and Middle Chinese reconstructions come from Pulleyblank (1991).

\section{Acknowledgement}

I would like to thank Sven Osterkamp, Wayne Lawrence, Laurent Sagart, Anton Antonov, and J. Marshall Unger for providing useful comments and suggestions on earlier drafts. All remaining errors are mine.

\section{References}

Asato, Susumu \& Naomi Doi. 1999. Okinawa-jin wa doko kara kita ka? Ryūkyū=Okinawa-jin no kigen to seiritsu. Naha: Bōdā inku.

Asato, Susumu, Kurayoshi Takara, Masayuki Dana, Kazuyuki Tomiyama, Kikō Nishizato \& Fusaaki Maehira. 2004. Okinawa-ken no rekishi. Tokyo: Yamagawa shuppan.

Aso, Reiko. 2010. Hateruma (Yaeyama Ryukyuan). In Michinori Shimoji \& Thomas Pellard (eds.), An Introduction to Ryukyuan languages, 189-227. Tokyo: ILCAA.

Atkinson, Quentin D. \& Russell D. Gray. 2005. Curious parallels and curious connections: Phylogenetic thinking in biology and historical linguistics. Systematic Biology 54(4): 513-526.

Atkinson, Quentin D., Andrew Meade, Chris Venditti, Simon J. Greenhill \& Mark Pagel. 20o8. Languages evolve in punctuational bursts. Science 319(5863): 588 .

Barnes, Gina L. 2007. State formation in Japan: Emergence of a 4th-century elite. New York: Routledge. 
Bellwood, Peter \& Colin Renfrew. 2002. Farmers, foragers, languages, genes: The genesis of agricultural societies. In Peter Bellwood \& Colin Renfrew (eds.), Examining the farming/language dispersal hypothesis, 17-31. Cambridge: McDonald Institute for Archaeological Research.

Bentley, John R. 2008. A linguistic history of the forgotten islands: A reconstruction of the protolanguage of the Southern Ryukyus. Folkestone: Global Oriental.

Bergsland, Knut \& Hans Vogt. 1962. On the validity of glottochronology. Current Anthropology 3(2): $115^{-153 .}$

Blust, Robert. 200o. Why lexicostatistics doesn't work: The 'universal constant' hypothesis and the Austronesian languages. In Colin Renfrew, April McMahon \& Larry Trask (eds.), Time depth in historical linguistics, 311-332. 2 vols. Cambridge: McDonald Institute for Archaeological Research.

Diamond, Jared \& Peter Bellwood. 2003. Farmers and their languages: The first expansions. Science 300(5619): 597-603.

Forster, Peter \& Colin Renfrew (eds.). 20o6. Phylogenetic methods and the prehistory of languages. Cambridge: McDonald Institute for Archaeological Research.

Frellesvig, Bjarke. 2010. A history of the Japanese language. Cambridge: Cambridge University Press.

Gray, Russell D. \& Quentin D. Atkinson. 2003. Language-tree divergence times support the Anatolian theory of Indo-European origin. Nature 426: 435-439.

Greenhill, Simon J. \& Russell Gray. 2005. Testing population dispersal hypotheses: Pacific settlement, phylogenetic trees, and Austronesian languages. In Ruth Mace, Clare J. Holden \& Stephen Shennan (eds.), The Evolution of cultural diversity: Phylogenetic approaches, 31-52. London: University College London Press.

Haneji, Kuniaki, Tsunehiko Hanihara, Hajime Sunakawa, Takashi Toma \& Hajime Ishida. 2007. Non-metric dental variation of Sakishima Islanders, Okinawa, Japan: A comparative study among Sakishima and neighboring populations. Anthropological Science 115(1): 35-45.

Hattori, Shirō. 1955. Ryūkyūgo V Bunpō. In Sanki Ichikawa \& Shirō Hattori (eds.), Sekai gengo gaisetsu, vol. 2, 328-353. Tokyo: Kenkyūsha.

Hattori, Shirō. 1958. Amami guntō no shohōgen ni tsuite: Okinawa/Sakishima shohōgen to no hikaku. Jinrui Kagaku XI: 79-99.

Hattori, Shirō. 1959. Nihongo no keitō. Tokyo: Iwanami shoten.

Hattori, Shirō. 1976. Ryūkyū hōgen to hondo hōgen. In Iha Fuyū tanjō hyakunen kinenkai (ed.), Okinawagaku no reimei, 7-55. Tokyo: Okinawa bunka kyōkai.

Hattori, Shirō. 1978-1979. Nihon sogo ni tsuite 1-22. Gengo 7(1)-7(3), 7(6)-8(12):

Heinrich, Patrick, Shinsho Miyara \& Michinori Shimoji (eds.). 2015. Handbook of the Ryukyuan languages: History, structure, and use. Berlin; Boston: De Gruyter Mouton.

Hirayama, Teruo (ed.). 1983. Ryūkyū Miyako shotō hōgen kiso goi no sōgōteki kenkyū. Tokyo: Ōfūsha.

Hirayama, Teruo (ed.). 1986. Amami hōgen kiso goi no kenkyū. Tokyo: Kadokawa shoten.

Hirayama, Teruo (ed.). 1988. Minami Ryūkyū no hōgen kiso goi. Tokyo: Ōfūsha.

Hirayama, Teruo (ed.). 1992-1994. Gendai Nihongo hōgen daijiten. 9 vols. Tokyo: Meiji shoin.

Hirayama, Teruo, Ichirō Ōshima \& Masachie Nakamoto. 1967. Ryūkyū Sakishima hōgen no sōgōteki kenkyū. Teruo Hirayama (ed.). Tokyo: Meiji shoin.

Hudson, Mark. 1994. The linguistic prehistory of Japan: Some archaeological speculations. Anthropological Science 102(3): 231-255.

Ikema, Nae. 2003. Yonagunigo jiten. Privately published.

Karimata, Shigehisa. 1996. Kagoshima-ken ōshima-gun Setouchi-chō Shodon hōgen no fonēmu (ge). Nihon Tōyō Bunka Ronshū (2):1-57.

Karimata, Shigehisa. 1999. Onsei no men kara mita Ryūkyū shohōgen. In Gengogaku kenkyūkai (ed.), Kotoba no kagaku 9, 13-85. Tokyo: Mugi shobō.

Karimata, Shigehisa. 200o. Tarama hōgen no keifu: Tarama hōgen wo rekishi hōgengakuteki kanten kara miru. In Kurayoshi Takara (ed.), Okinawa-ken Tarama-jima ni okeru dentōteki shakai shisutemu no jittai to hen'yō ni kansuru sōgōteki kenkyū, 27-37. Nishihara: Ryūkyū daigaku hōbungakubu.

Katō, Masanobu. 1977. Hōgen kukakuron. In Susumu Ōno \& Takeshi Shibata (eds.), Iwanami kōza Nihongo 11: Hōgen, 41-82. Tokyo: Iwanami shoten. 
Keegan, William F. \& Jared M. Diamond. 1987. Colonization of islands by humans: A biogeographical perspective. Advances in Archaeological Method and Theory 10: 49-92.

Kibe, Nobuko, Haruo Kubozono, Kayoko Shimoji, Wayne Lawrence, Akiko Matsumori \& Kōko Takeda. 2011. Shōmetsu kiki hōgen no chōsa/hozon no tame no sōgōteki kenkyū: Kikai-jima hōgen chōsa hōkokusho. Tachikawa: NINJAL.

Kiku, Chiyo \& Toshizō Takahashi. 2005. Yoron hōgen jiten. Tokyo: Musashino shoin.

Kinoshita, Naoko. 2003. Kai kōeki to kokka keisei: 9 seiki kara 13 seiki wo taishō ni. In Naoko Kinoshita (ed.), Senshi Ryūkyū no seigyō to kōeki: Amami-Okinawa no hakkutsu chōsa kara, 117144. JSPS Research Report 11410107. Kumamoto: Kumamoto University.

Kokuritsu kokugo kenkyūjo (ed.). 1963. Okinawago jiten. Tokyo: Ōkurashō insatsukyoku.

Lawrence, Wayne P. 20oo. Yaeyama hōgen no kukaku ni tsuite. In Shigeru Ishigaki (ed.), Miyanaga Masamori kinen ronshū, 547-559. Ishigaki: Miyanaga Masamori tanjō hyakunen kinen jigyō kiseikai.

Lawrence, Wayne P. 2003. Tarama hōgen no keitōteki ichi. In Daiyonkai Okinawa kenkyū shinpojiamu jikkō iinkai (ed.), Sekai ni hiraku Okinawa kenkyū: Okinawa kenkyū kokusai shinpojiamu Yōroppa taikai, 238-247. Naha: Daiyonkai Okinawa kenkyū shinpojiamu jikkō iinkai.

Lawrence, Wayne P. 2006. Okinawa hōgengun no kai kubun ni tsuite. Okinawa Bunka 40(2/100): 101-118.

Lawrence, Wayne P. 2008. Yonaguni hōgen no keitōteki ichi. Ryūkyū no Hōgen 32: 59-67.

Lee, Sean \& Toshikazu Hasegawa. 2011. Bayesian phylogenetic analysis supports an agricultural origin of Japonic languages. Proceedings of the Royal Society B: Biological Sciences 278(1725): 3662-3669.

Li, Shi-Lin, Toshimichi Yamamoto, Takashi Yoshimoto, Rieko Uchihi, Masaki Mizutani, Yukihide Kurimoto, Katsushi Tokunaga, Feng Jin, Yoshinao Katsumata \& Naruya Saitou. 20o6. Phylogenetic relationship of the populations within and around Japan using 105 short tandem repeat polymorphic loci. Human Genetics 118(6): 695-707.

Mabuchi, Kazuo. 1994. Kokugo on'inron. Tokyo: Kasama shoin.

Maeara, Tōru. 2011. Taketomi hōgen jiten. Ishigaki: Nanzansha.

Maeō, Yōan. 2002. Iriomote hōgen shū. Privately published.

Martin, Samuel E. 1970. Shodon: A dialect of the Northern Ryukyus. Journal of the American Oriental Society 9o(1): 97-139.

Martin, Samuel E. 1987. The Japanese language through time. New Haven; London: Yale University Press.

Matsukusa, Hirotaka, Hiroki Oota, Kuniaki Haneji, Takashi Toma, Shoji Kawamura \& Hajime Ishida 2010. A genetic analysis of the Sakishima islanders reveals no relationship with Taiwan aborigines but shared ancestry with Ainu and main-island Japanese. American Journal of Physical Anthropology 142(2): 211-223.

Matsumori, Akiko. 1998. Ryūkyū akusento no rekishiteki keisei katei: Ruibetsu goi 2-hakugo no tokui na gōryū no shikata o tegakari ni. Gengo Kenkyū 114: 85-114.

Matsumori, Akiko. 200oa. Ryūkyū akusento chōsa no tame no ruibetsu goi no kaihatsu: Okinoerabujima no chōsa kara. Onsei kenkyū 4(1): 61-71.

Matsumori, Akiko. 2ooob. Ryūkyū no takei akusento taikei ni tsuite no ichi kōsatsu: Ryūkyū sogo ni okeru ruibetsu goi 3-paku go no gōryū no shikata. Kokugogaku 51(1): 93-108.

Millien, Virginie. 2006. Morphological evolution is accelerated among island mammals. PLoS Biol 4(10): e321.

Miyagi, Shin'yū. 2003. Ishigaki hōgen jiten. 2 vols. Naha: Okinawa taimusu.

Nakasone, Seizen. 1983. Okinawa Nakijin hōgen jiten. Tokyo: Kadokawa shoten.

Nichols, Johanna. 1997. Modeling ancient population structures and movement in linguistics. Annual Review of Anthropology 26: 359-384.

Osada, Suma \& Nahoko Suyama. 1977-1980. Amami hōgen bunrui jiten. 2 vols. Tokyo: Kasama shoin.

Oshio, Mutsuko. 1999. Okinawa Ie-jima hōgen jiten. 2 vols. Ie-son: Ie-son kyōiku iinkai.

Ōshiro, Ken. 1972. Goitōkeigaku (gengo nendaigaku) teki hōhō ni yoru Ryūkyū hōgen no kenkyū. In Hattori Shirō sensei teinen taikan kinen ronbunshū henshū iinkai (ed.), Gendai gengogaku, 533-558. Tokyo: Sanseidō. 
Pearson, Richard. 2001. Archaeological perspectives on the rise of the Okinawan state. Journal of Archaeological Research 9 (3): 243-285. ISSN: 1059-0161.

Pellard, Thomas. 2008. Proto-Japonic *e and *o in Eastern Old Japanese. Cahiers de Linguistique Asie Orientale 37(2): 133-158.

Pellard, Thomas. 2009. Ōgami: éléments de description d'un parler du Sud des Ryūkyū. École des hautes études en sciences sociales $\mathrm{PhD}$ thesis.

Pellard, Thomas. 2013. Ryukyuan perspectives on the proto-Japonic vowel system. In Bjarke Frellesvig \& Peter Sells (eds.),Japanese/Korean Linguistics 20, 81-96. Stanford: CSLI Publications.

Pietrusewsky, Michael. 1999. A multivariate craniometric study of the inhabitants of the Ryukyu Islands and comparisons with cranial series from Japan, Asia, and the Pacific. Anthropological Science 107(4): 255-281.

Pulleyblank, Edwin G. 1991. Lexicon of reconstructed pronunciation in Early Middle Chinese, Late Middle Chinese, and Early Mandarin. Vancouver: UBC Press.

Renfrew, Colin. 1992. Archaeology, genetics and linguistic diversity. Man 27(3): 445-478.

Sagart, Laurent. 2004. The higher phylogeny of Austronesian and the position of Tai-Kadai. Oceanic Linguistics 43(2): 411-444.

Sapir, Edward. 1916. Time perspective in aboriginal American culture, a study in method. Geological Survey Memoir 9o: No. 13, Anthropological Series. Ottawa: Government Printing Bureau.

Serafim, Leon. 1994. Linguistically, what is Ryukyuan? Synchronic and diachronic perspectives. In Second international symposium of the International Society for Ryukyuan Studies. 24 March. Harvard University.

Serafim, Leon A. 2003. When and from where did the Japonic language enter the Ryukyus? In Alexander Vovin \& Toshiki Osada (eds.), Nihongo keitöron no genzai (Perspectives on the origins of the Japanese language), 463-476. Kyoto: Kokusai Nihon bunka sentā.

Serafim, Leon A. 2008. The uses of Ryukyuan in understanding Japanese language history. In Bjarke Frellesvig \& John Whitman (eds.), Proto-Japanese: Issues and prospects, 79-99. Amsterdam; Philadelphia: John Benjamins.

Shinoda, Ken-ichi \& Naomi Doi. 20o8. Mitochondrial DNA analysis of human skeletal remains obtained from the old tomb of Suubaru: Genetic characteristics of the westernmost island Japan. Bulletin of the National Museum of Nature and Science. Series D, Anthropology 34:11-18.

Shirata, Rihito, Masahiro Yamada, Chisako Ogino \& Yukinori Takubo. 2011. Ryūkyūgo Kikai-jima Kamikatetsu hōgen no danwa shiryō. Chikyūken Gengo Kijutsu Ronshū 3: 111-152.

Shōda, Shinya. 2007. A comment on the Yayoi period dating controversy. Bulletin of the Society for East Asian Archaeology 1: 1-7.

Summerhayes, Glenn R. \& Atholl Anderson. 20og. An Austronesian presence in southern Japan: Early occupation in the Yaeyama Islands. Bulletin of the Indo-Pacific Prehistory Association 29: $76-91$.

Tajima, Atsushi, Masanori Hayami, Katsushi Tokunaga, Takeo Juji, Masafumi Matsuo, Sangkot Marzuki, Keiichi Omoto \& Satoshi Horai. 2004. Genetic origins of the Ainu inferred from combined DNA analyses of maternal and paternal lineages. Journal of Human Genetics 49: 187-193.

Takamiya, Hiroto. 20o1. Introductory routes of rice to Japan: An examination of the Southern route hypothesis. Asian Perspectives 40(2): 209-226.

Takamiya, Hiroto. 2005. Shima no senshigaku: Paradaisu dewanakatta Okinawa shotō no senshi jidai. Naha: Bōdā inku.

Takanashi, Osamu, Minako Abe, Ken Nakamoto \& Naoki Yoshinari. 20og. Okinawa bunka wa doko kara kita ka: Gusuku jidai to iu kakki. Tokyo: Shinwasha.

Thorpe, Maner L. 1983. Ryūkyūan language history. University of Southern California PhD thesis.

Toma, Takashi, Tsunehiko Hanihara, Hajime Sunakawa, Kuniaki Haneji \& Hajime Ishida. 2007. Metric dental diversity of Ryukyu Islanders: A comparative study among Ryukyu and other Asian populations. Anthropological Science 115(2): 119-131.

Trudgill, Peter. 1974. Linguistic change and diffusion: Description and explanation in sociolinguistic dialect geography. Language in Society 3(2): 215-246.

Uchima, Chokujin \& Kumiko Aragaki. 20oo. Okinawa hokubu/nanbu no kijutsuteki kenkyū. Tokyo: Kazama shobō. 
Uemura, Yukio. 1997. Ryūkyū rettō no gengo: Sōsetsu. In Takashi Kamei, Rokurō Kōno \& Ei'ichi Chino (eds.), Nihon rettō no gengo, 311-354. Tokyo: Sanseidō.

Unger, J. Marshall. 2009. The role of contact in the origins of the Japanese and Korean languages. Honolulu: University of Hawai'i press.

Uwano, Zendō. 20og. Ryūkyū Yonaguni hōgen no akusento shiryō (1). Ryūkyū no Hōgen 34: 1-30.

Whitman, John. 2012. Northeast Asian linguistic ecology and the advent of rice agriculture in Korea and Japan. Rice 4(3-4): 149-158.

Yanagida, Seiji. 1993. Muromachi-jidaigo o tōshite mita Nihongo on'inshi. Tokyo: Musashino shoin. Yanagita, Kunio. 1952. Kaijō no michi. Tokyo: Iwanami shoten. 